\title{
Purification and Partial Characterization of Trypanosoma cruzi Triosephosphate Isomerase
}

\author{
SC Bourguignon $/{ }^{+}$, MN Meirelles*, RS Pacheco**, S Giovanni De Simone/*/++
}

Departamento de Biologia Celular e Molecular, Instituto de Biologia, Universidade Federal Fluminense, Niterói, RJ, Brasil *Departamento de Ultraestrutura Celular **Laboratório de Sistemática Bioquímica ***Laboratório de Microseqüenciamento de Proteínas, Departamento de Bioquímica e Biologia Molecular, Instituto Oswaldo Cruz,

Av. Brasil 4365, 21045-900 Rio de Janeiro, RJ, Brasil

The enzyme triosephosphate isomerase (TPI, EC 5.3.1.1) was purified from extracts of epimastigote forms of Trypanosoma cruzi. The purification steps included: hydrophobic interaction chromatography on phenyl-Sepharose, CM-Sepharose, and high performance liquid gel filtration chromatography. The CM-Sepharose material contained two bands (27 and $25 \mathrm{kDa}$ ) with similar isoelectric points ( $\mathrm{pI}$ 9.39.5) which could be separated by gel filtration in high performance liquid chromatography. Polyclonal antibodies raised against the porcine TPI detected one single polypeptide on western blot with a molecular weight $(27 \mathrm{kDa}$ ) identical to that purified from $\mathrm{T}$. cruzi. These antibodies also recognized only one band of identical molecular weight in western blots of several other trypanosomatids (Blastocrithidia culicis, Crithidia desouzai, Phytomonas serpens, Herpertomonas samuelpessoai). The presence of only one enzymatic form of TPI in T. cruzi epimastigotes was confirmed by agarose gel activity assay and its localization was established by immunocytochemical analysis. The T. cruzi purified TPI (as well as other trypanosomatid' TPIs) is a dimeric protein, composed of two identical subunits with an approximate $m w$ of 27,000 and it is resolved on two dimensional gel electrophoresis with a pI of 9.3. Sequence analysis of the $\mathrm{N}$-terminal portion of the $27 \mathrm{kDa}$ protein revealed a high homology to Leishmania mexicana and $\mathrm{T}$. brucei proteins.

Key words: Trypanosoma cruzi - triosephosphate isomerase - purification - sequence

Chagas' disease is caused by the protozoan hemoflagellate Trypanosoma cruzi. This and other kinetoplastids are distinguished from diverse eucaryotic cells by the presence of glycosomes, a microbody-like organelle containing glycolytic and glycerol metabolic enzymes (Opperdoes 1987, Michels 1989, Blattner et al. 1992). Corresponding glycolytical isoenzymes were also found to be present in the cytoplasm of most protozoa studied so far. Most of these proteins are encoded by different genes (Sullivan et al. 1985, Huang et al. 1989) and the glycosomal enzymes are synthesised in the cytoplasm by free ribosomes and imported post-translationally without apparent cleavage or modification. Several of these glycosomal and cytosolic isoenzymes have been purified from $T$. brucei (Misset et al. 1986, 1987) and T. cruzi (Bourguignon et al. 1997) and were distinguished

\footnotetext{
Suported in part by CNPq, Finep and Fiocruz.

${ }^{+}$Recipient of a CNPq fellowship.

${ }^{++}$Corresponding author. Fax: $+55-21-590.3495$. E-mail: dsimone@gene.dbbm.fiocruz.br

Received 20 May 1997

Accepted 5 November 1997
}

structurally from their mammalian counterparts (Michels \& Opperdoes 1991). In view of this and based on the observation that the inhibition of some glycosomal enzymes from T. brucei (Durieux et al. 1991) may result in the death of the parasite (Opperdoes et al. 1990, Willson et al. 1993) these enzymes have suggested as promising targets for drug design.

The T. brucei (Swinkels et al. 1986) and Leishmania mexicana (Kokl et al. 1994) triose-phosphate isomerase (TPI, EC 5.3.1.1) genes have been cloned and characterized. This enzyme was shown to be a dimer composed by identical subunits and it was also shown to catalyze the isomerization of the two products of aldolase, D-glyceraldehyde 3phosphate and dihydroxyacetone phosphate, in the absence of carbohydrates. Moreover, it presents a key position in the metabolism, generating dihydroxyacetone phosphate in anaerobic condition, through reverse action of the glycerol kinase and glyceraldehyde-phosphate dehydrogenase. The overall structures of these enzymes are strictly conserved despite substantial variation, and approximately $50 \%$ in its amino acid sequence has remained identical (Fothergill-Gilmore \& Michels 1993). In this work we describe the purification and partial characterization of the TPI enzyme from 
T. cruzi . In addition, using an enzymatic assay by agarose gel electrophoresis we show that the $T$. cruzi Dm28c clone expresses only one form of this enzyme.

\section{MATERIALS AND METHODS}

Materials - Phenyl- and CM-Sepharose were obtained from Pharmacia Fine Chemicals (Uppsala, Sweden); ethylenediamino tetratacetic acid (EDTA), dithiotreitol (DTT), ammonium sulfate, rabbit GAPDH, agarose, trietanolamine, porcine TPI, nonidet P40 (NP40), (3-[4,5-dimethylthiazol$2 \mathrm{yl}]_{5}-2,5$ diphenyltetrazolium bromide) (MTT), phenazine metnosulfate (PMS), glutaraldehyde, paraformaldehyde, cacodilate, chromatographic weight standard proteins and goat anti-rabbit peroxidase conjugated from Sigma Chemical Co. (St. Louis, Mo, U.S.A.); ampholines, silver staining kit, SDS-molecular weight standard proteins, poly (vinylidenedifluoride) (PVDF) and nitrocellulose membrane from Bio-Rad (Richmond, CA, U.S.A.). The Shinpack Diol-150 HPLC column and the sequencing reagents were from Wako Pure Chemicals (Richmond, CA, U.S.A.) while the electrophoresis reagents were obtained from Serva (Heidelberg, Germany). Freund's adjuvants and P10 filters were from Gibco and Amicon (Beverly, MA, U.S.A.) respectively. Liver infusion tryptose (LIT) and brain heart infusion-tryptose (BHI) medium were obtained from Difco (Detroit, Michigan, U.S.A.). All other reagents and chemicals were from Merck (Darmstadt, Germany).

Parasites - Epimastigote forms from Dm 28c clone were maintained in liver infusion tryptose (LIT) medium (Contreras et al. 1985) while amastigotes from cellular culture were maintained according to Giovanni De Simone et al. (1987). Blastocrithidia culicis, Crithidia desouzai, Phytomonas serpens, L. guianensis and Herpertomonas samuelpessoai were cultivated in BHI medium (Giovanni De Simone et al. 1987). All parasites were harvested at log phase and washed three times by centrifugation $(3,000 \mathrm{~g}, 10 \mathrm{~min})$ in PBS.

Extraction of the enzyme and binding to phenyl-Sepharose column - After washes with PBS, T. cruzi epimastigote forms were freeze-thawed three times in the same buffer and the insoluble material was pelleted by centrifugation $(40,000 \mathrm{~g}$, $30 \mathrm{~min}, 4^{\circ} \mathrm{C}$ ). The supernatant was designed crude extract and ammonium sulfate was added to a final concentration of $1 \mathrm{M}$. The extract was applied to a $20 \mathrm{ml}$ phenyl-Sepharose CL-4B column equilibrated with $25 \mathrm{mM}$ Tris- $\mathrm{HCl} \mathrm{pH} 7.8$, containing 5 mM EDTA, 1mM DTT and $1 \mathrm{M}\left(\mathrm{NH}_{4}\right)_{2} \mathrm{SO}_{4}$ and fractionated using an ammonium sulfate reverse gradient.
Cation-exchange chromatography - After release from phenyl-Sepharose, the fraction (peak 3 ) was concentrated on a Centripep P10 filter followed by replacement of the buffer $(0.1 \mathrm{M}$ trietanolamine- $\mathrm{HCl} \mathrm{pH} 8.0$ containing $1 \mathrm{mM}$ EDTA) and fractionation of the sample on a fast flow CM-Sepharose column. Fractions of $3 \mathrm{ml}$ were collected and concentrated, separately, using Centripep P10 filters and analyzed by sodium dodecyl sulfate polyacrylamide gel electrophoresis (SDS-PAGE).

Size exclusion HPLC - The CM-Sepharose pooled peak 2 was concentrated using centricon filters and injected in a Shinpack Diol-150 HPLC column ( $5 \mathrm{~mm}$; $50 \mathrm{~cm}$ x $7.9 \mathrm{~mm}$ I.D.), previously equilibrated in $50 \mathrm{mM}$ phosphate buffer, $\mathrm{pH} 7.2$. The proteins were fractioned on an automatic HPLC system (Shimadzu, 6A model) during 28 min at $25^{\circ} \mathrm{C}$ (Fig. 4). Fractions of $1 \mathrm{ml}$ were collected and concentrated as described before. For molecular mass characterization the column was calibrated in the same buffer with the following markers: b-galactosidase (105 kDa), bovine serum albumin $(66 \mathrm{kDa})$, ovalbumin $(45 \mathrm{kDa})$ and carbonic anhydrase $(29 \mathrm{kDa})$.

One and two-dimensional PAGE - One-dimensional SDS-PAGE was performed using polyacrylamide gels in Laemmli buffers (Laemmli 1970) under reduction conditions. Two-dimensional PAGE (2D-PAGE) consisted of isotachophoresis followed by electrophoretic analysis on uniform 15\% SDS-PAGE (O' Farrel et al. 1977). The gels were stained with Coomassie blue R-250 or silver (Bio-Rad silver stain kit). Bovine serum albumin (BSA $66 \mathrm{kDa})$, hen egg white ovalbumin $(45 \mathrm{kDa})$, bovine carbonic anhydrase ( $29 \mathrm{kDa})$, and hen egg white lysozyme $(14,4 \mathrm{kDa})$ were used as standards for characterization of molecular mass.

Agarose gel electrophoresis - This electrophoresis was conduced in a Multifor apparatus using a continuous buffer $(414 \mathrm{mM}$ Tris and 50 $\mathrm{mM}$ citric acid $\mathrm{pH} 8.1)$ under $50 \mathrm{~V}$ in a watercooled apparatus for approximately $2 \mathrm{hr}$ ( Harry \& Hopkinson 1976). Afterwards the gels were removed, washed (0.2 M Tris-HCl, $\mathrm{pH} 8.0)$ and incubated in the same buffer $(50 \mathrm{ml})$ containing $0.1 \%$ $(\mathrm{w} / \mathrm{v})$ of sodium pyruvate and sodium arsenate, $20 \%(\mathrm{w} / \mathrm{v}) \mathrm{NAD}^{+}, 4 \%(\mathrm{w} / \mathrm{v})$ MTT and $2 \%(\mathrm{w} / \mathrm{v})$ PMS. The staining was allowed to proceed at $25^{\circ} \mathrm{C}$ in the dark. Extract from L. guianensis was run simultaneously and the development of the TPI used as internal standard.

Preparation of anti-TPI antibodies - Polyclonal antibodies were raised in rabbits by subcutaneous injection of $20 \mathrm{mg}$ commercially available porcine TPI protein emulsified with complete (first booster) and incomplete (second and third booster) Freund's 
adjuvant. The animals were bled seven days after the last booster injection. Antibody title and specificity were evaluated by ELISA and western blotting.

Immunocytochemistry - T. cruzi epimastigote and amastigote forms were processed for Lowicryl $\mathrm{K} 4 \mathrm{M}$ at $-20^{\circ} \mathrm{C}$ as previously described (Bendayan et al. 1987). Ultra-thin sections were cut with a RMC MT-7 ultramicrotome and sequentially labelled with polyclonal antibody anti-TPI (diluted in TBS $0.1 \mathrm{M}$, BSA $1 \%$, Tween $1 \%)$ and $(1: 10$ dilution) of protein A-gold complexes (15 nm). Photographs were taken using a Zeiss EM 10C electron microscope (Fig. 7).

Western-blotting and protein estimation Immunoblots were performed according Towbin and Gordon (1979) and protein was estimated by the Lowry's method (Lowry et al. 1951).

Protein microsequencing - For sequencing experiments, the isolated protein was analyzed directly by the polybrene method or it was run a $15 \%$ acrylamide SDS-PAGE (Laemmli 1970) and blotted onto a PVDF membrane using a semidry blotting apparatus. $\mathrm{NH}_{2}$-terminal amino acid sequence analysis was performed by automatic Edman degradation using a gas-phase protein microsequencer (Model PSQ-1; Shimadzu) coupled to an on line HPLC system (model 6A; Shimadzu) using the conditions described by Giovanni De Simone et al. (1994). The obtained amino acid sequence was compared with the GenBank and Swiss-PROT protein database.

\section{RESULTS AND DISCUSSION}

In this work we report the purification, in apparent homogeneity, of triose phosphate isomerase from $T$. cruzi epimastigote forms by combining phenyl-Sepharose, CM-Sepharose and gel filtration high performance liquid chromatography. The soluble freeze-thawed extract $(40,000 \mathrm{~g})$ of $T$. cruzi was fractionated by phenyl-Sepharose column using an ammonium sulfate reverse gradient (Fig. 1). When the fraction 3 was subsequently applied to a CM-Sepharose column at $\mathrm{pH}$ 8.0, four principal peaks were revealed. The TPI activity was eluted at $45-70 \mathrm{mM}$ of $\mathrm{NaCl}$ (Fig. 2). The SDS-PAGE analysis showed that the peak 1 contained proteins with 27 and $15 \mathrm{kDa}$ (Fig. 2, lane A) while the peak 2 represented bands with approximately 27 and 25 $\mathrm{kDa}$ (Fig. 2 lane B, insert). These last two proteins presented a similar isoelectric point 9.3-9.5 (data not shown), however by western blot studies using the rabbit sera anti-TPI (Fig. 3), it was shown that only the $27 \mathrm{kDa}$ molecular species was the immuno active protein.

In order to purify homogeneously and to determine the Mr of the TPI component in the native state, a gel filtration-fractionation protocol was performed. The cross reactive component (peak 1) was eluted with an approximate Mr of about 55,000 (Fig. 4) suggesting that the enzyme was a dimeric protein. Subsequent SDS-PAGE analysis confirmed the purification (data not shown).

The partial $\mathrm{N}$-terminal sequence data analysis of the first 15 amino acid of the protein revealed $93 \%$ and $100 \%$ of homology with the TPI from $T$. brucei and L. mexicana, respectively (Table). This high homology in TPI of different organisms is reinforced by the results of the immunoblot tests. The use of a heterologous serum anti-TPI revealed only one identical migrating band in different parasites (B. culicis, P. serpens, C. desouzai, H. samuel-

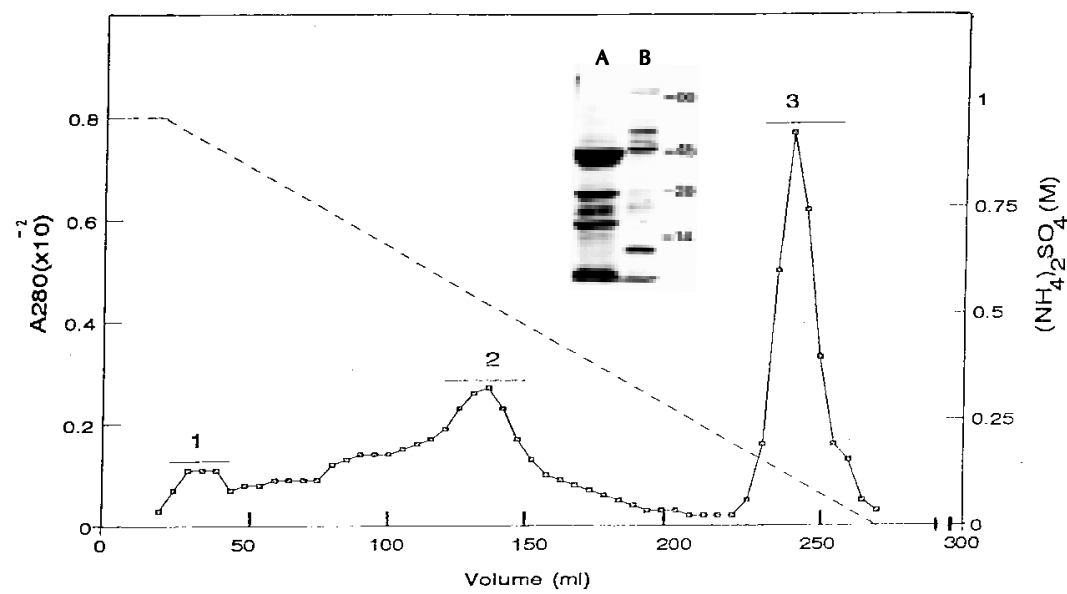

Fig. 1: hydrophobic chromatography on a phenyl-Sepharose column $(12.5 \times 1.5 \mathrm{~cm}$, I.D.) and SDS-PAGE (12\%) of the freezethawing epimastigote supernatant. The column was equilibrated in $25 \mathrm{mM}$ Tris- $\mathrm{HCl} \mathrm{pH} 7.8$ containing $5 \mathrm{mM}$ EDTA, $1 \mathrm{mM}$ DTT, 1 $\mathrm{mM} \mathrm{NaN}_{3}$ and $1 \mathrm{M}\left(\mathrm{NH}_{4}\right)_{2} \mathrm{SO}_{4}$. Fractions of $5 \mathrm{ml}$ were collected from the column at flow rate of $20 \mathrm{ml} \mathrm{h}^{-1}$ using a reverse gradient of $\left(\mathrm{NH}_{4}\right)_{2} \mathrm{SO}_{4}(100 \%-0 \%)$ in the same buffer. Coomassie stained, SDS-gel electrophoresis of fraction 2 (A) and 3 (B) are shown inside the figure. The molecular weight of the standard proteins are shown in the right side. 


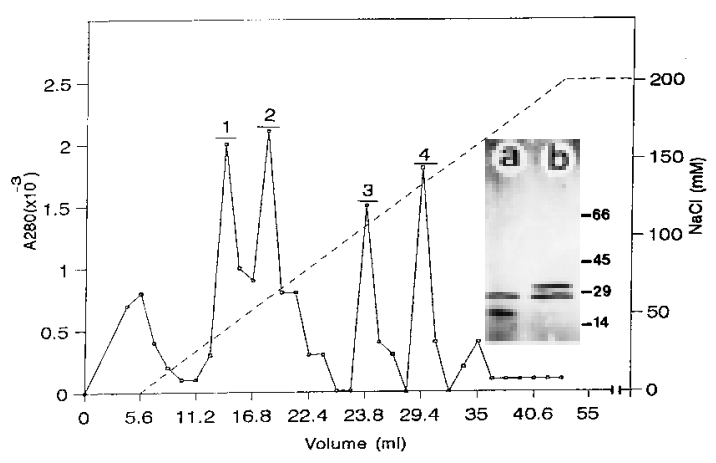

Fig. 2: cation exchange chromatography of the triosephosphate isomerase fraction (peak 3, Fig. 1) and SDS-PAGE (12\%) of the main peak 1 (a) and 2 (b) recovered from CM-Sepharose column followed by silver staining. The molecular weight of the standard proteins are shown in the right side. The CMSepharose column $(6.5 \times 1.0 \mathrm{~cm}$, I.D. $)$ was equilibrated with 25 $\mathrm{mM}$ Tris- $\mathrm{HCl}, \mathrm{pH} 8.0$, buffer and the fractions $(1,4 \mathrm{ml})$ collected at a flow rate of $5 \mathrm{ml} \mathrm{h}^{-1}$ using a gradient of $\mathrm{NaCl}(0-200$ $\mathrm{mM})$ in the same buffer.

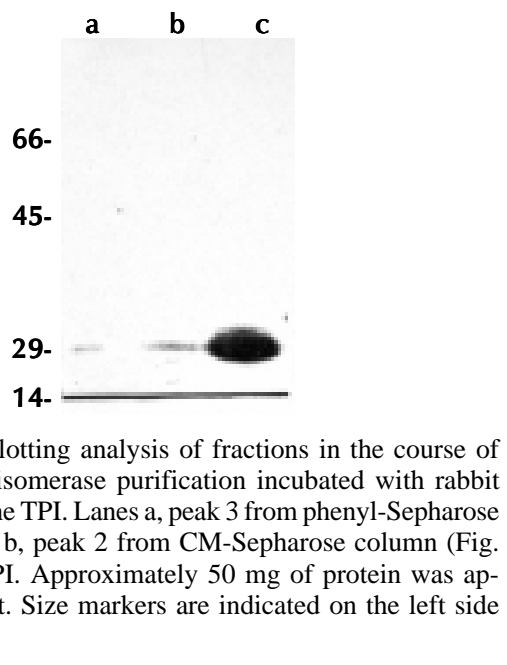

pessoai) extracts (Fig. 5), suggesting that only one form of enzyme exists in these parasites including T. cruzi (Fig. 3).

Highly active preparation of TPI has been obtained from T. brucei isolated glycosomes (Misset \& Opperdoes 1984, Misset et al. 1986), however the number of this organelle in this parasite is four times greater than in T. cruzi (Soares \& De Souza 1988, Tetley \& Vickerman 1990). These observations may indicate difficulty to obtain the TPI directly from $T$. cruzi purified organelle. Therefore for purify the TPI we decided to use the supernatant of the total extract after freeze-thawing fractionation. Despite the presence of different putative enzyme forms as demonstrated in different cell types (Tang et al. 1990), only one form of TPI could be detected in $T$. cruzi epimastigotes by

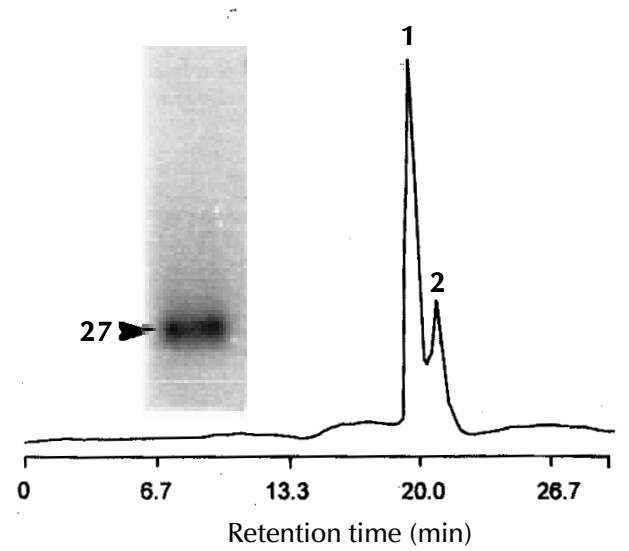

Fig. 4: gel filtration chromatography analysis of the CMSepharose triosephosphate isomerase-containing peak 2 using a Shinpack Diol- 150 HPLC column $(50 \mathrm{~cm} \times 7.9 \mathrm{~mm}$, I.D. $)$ and SDS-PAGE (12\%) of the purified TPI (peak 1). About $100 \mathrm{mg}$ of protein was analyzed in the gel filtration column and elution performed using $50 \mathrm{mM}$ phosphate buffer ( $\mathrm{pH}$ 7.2) at a flow rate of $1 \mathrm{ml} \mathrm{min}^{-1}$. Absorbance was measured at $280 \mathrm{~nm}$ using AUFS $=4$. Arrow shows the coomassie blue stained protein (peak 1).

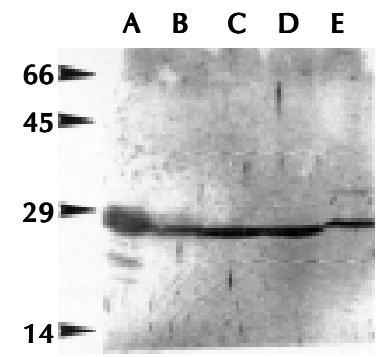

Fig. 5: immunological characterization of the triose phosphate isomerase from various trypanosomatids using the triose phosphate isomerase antiserum. A: porcine TPI; B: Blastocrithidia culicis; C: Phytomonas serpens; D: Crithidia desouzai; E: Herpertomonas samuelpessoai. Approximately $100 \mathrm{mg}$ of protein from the various species of parasite was applied in each slot. At the left side of the figure are indicated the molecular mass, in $\mathrm{kDa}$, of marker proteins.

immunoblotting (Fig. 3) and by agarose electrophoresis (Fig. 6) analysis. In addition, this last analysis demonstrated that the $T$. cruzi protein is more positively charged than the L. guinanenis TPI enzyme. This fact is strengthen by the demonstration of the lower isoelectric point (9.0) of $L$. mexicana mexicana TPI enzyme (Kohl et al. 1994).

Immunocytochemical studies showed that gold immunecomplexes were distributed in the cytoplasm of epimastigotes and amastigote cells and no gold particles were displayed delimiting glycosome organelles. Although a dual localization of a single TPI form has been described in Leishmania (Michels 1989), in our studies it is not 
TABLE

Comparison of the $\mathrm{N}$-terminal amino acid sequence of the Trypanosoma cruzi triosephosphate isomerase with translated triosephosphate isomerase sequences described in the literature

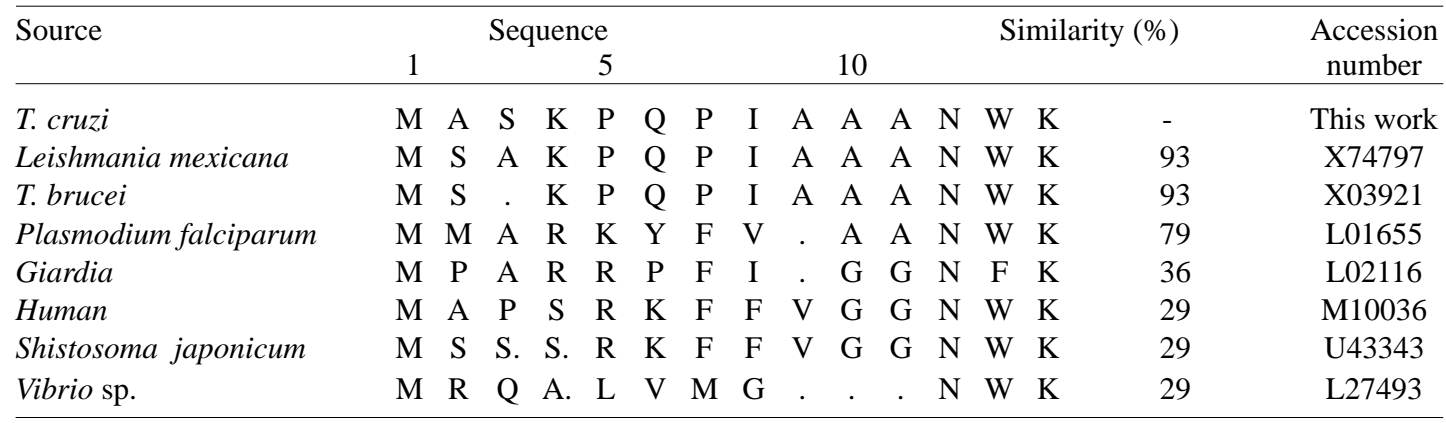

The numbering refers to $T$. cruzi sequence, and the dots gaps that have been introduced in order to align these sequences.

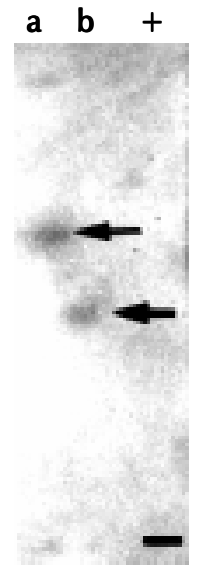

Fig. 6: agarose gel electrophoresis. Electrophoresis and the triosephosphate isomerase activity were developed as described under "Materials and Methods". a: Leishmnia guianensis crude extract; b: Trypanosoma cruzi crude extract. Arrows point to the stained bands.

clear whether glycosomes were detected by the electron micrography depicted. This fact did not eliminate the possibility of a dual localization of the $T$. cruzi TPI protein. Indeed the anaerobic pathway is used by amastigote forms while the aerobic oxidation of substrates, such as amino acids (Engel et al. 1987) and fatty acids (Wood \& Shiller 1975) is preferred by epimastigote and trypomastigote, respectively. Therefore, we believe that similar to other parasites $T$. cruzi presents only one form of TPI with a possible dual (cytoplasm and glycosomes) localization. This assumption is supported by the western blotting results (Fig. 3) which detected only one reactive band in total $T$. cruzi extract, by the agarose electrophoresis activity analysis (Fig. 6) and by the cloning results from Kohl et al. (1994) which detected only one TPI gene for L. mexicana.

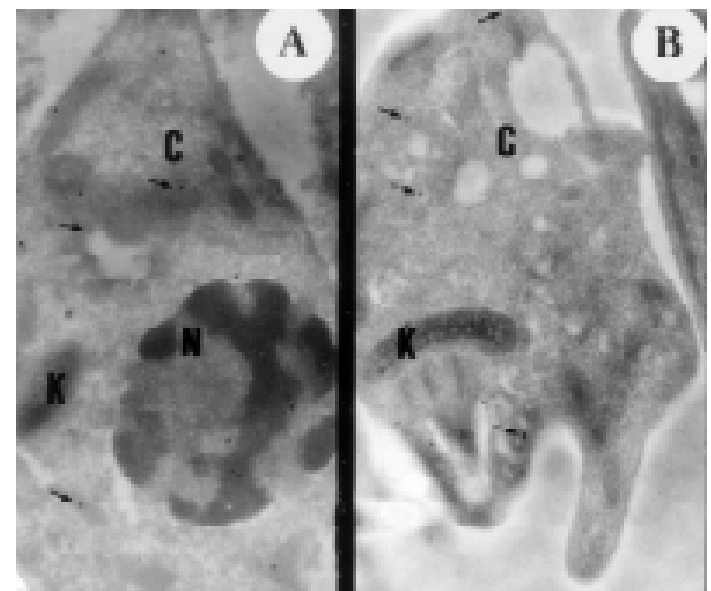

Fig. 7: thin sections of Lowicryl embedded cells incubated with rabbit anti-triosephosphate isomerase antibodies and protein Agold complexes. Labelling of the amastigote (A) and epimastigote (B) forms were evident in the cytoplasm (arrow). C: cytoplasm; K: kinetoplast and N: nucleus. (x 30.000).

In summary, we have been able to purify homogeneous $T$. cruzi TPI using an alternative procedure. The enzyme was localized preferentially in the cytoplasm of both amastigote and epimastigote forms and it showed a native molecular weight of $52 \mathrm{kDa}$ identical to other TPI studied thus far. Moreover, the T. cruzi enzyme differs from L. guianensis (as shown in this work), T. brucei (pI 9.8; Willson et al. 1993) and L. mexicana (pI 9.0; Kohl et al. 1994) TPIs in that its isoelectric point is slightly more acid and basic, respectively.

\section{ACKNOWLEDGEMENTS}

To M Ortigão for the formal revision of the manuscript and the Laboratório de Insumos e Conjugados do Instituto de Tecnologia (Biomanguinhos) of Fiocruz for yielding the peroxidase labelled goat-anti rabbit IgG. 


\section{REFERENCES}

Bendayan M, Nanci A, Kan FWK 1987. Effect of tissue processing on colloidal gold cytochemistry. $J$ Histochem Cytochem 35: 983-996.

Bourguignon SC, Alves CR, Giovanni De Simone S 1997. Detrimental effect of nitric oxide on Trypanosoma cruzi and Leishmanina major like cells. Acta Tropica 66: 109-118.

Blattner J, Swinkels B, Dörsam H, Prospero T, Subramani S, Clayton C 1992. Glycosome assembly in trypanosomes: variation in the acceptable degeneracy of a $\mathrm{COOH}$-terminal microbody targeting sinal. J Cell Biol 19: 1129-1136.

Contreras VT, Salles JM, Thomas N, Morel CM, Goldenberg S 1985. In vitro differentiation of Trypanosoma cruzi under chemically defined conditions. Molec Biochem Parasitol 16: 315-327.

Durieux PO, Schutz P, Brun R, Kohler P 1991. Alterations in Krebs cycle enzyme activities and carbohydrate catabolism in two strains of Trypanosona brucei during differentiation of their bloodstream to procyclic stages. Molec Biochem Parasitol 45: 19-28.

Engel JC, Cazzulo BMF, Stoppani AOM, Cannata JJB, Cazzulo JJ 1987. Aerobic glucose fermentation by Trypanosoma cruzi axenic culture amastigote-like forms during growth and differentiation to epimastigotes. Molec Biochem Parasitol 26: 1-10.

Fothergill-Gilmore LA, Michels PAM 1993. Evolution of glycolysis. Prog Biophys Molec Biol 59: 105-235.

Giovanni De Simone S, Pontes de Carvalho LC, Oliva OFP, Andrade S, Galvão-Castro B 1987. Trypanosoma cruzi strain specific monoclonal antibodies: Identification of Colombian strain flagellates in the insect vector. Trans $R$ Soc Trop Med Hyg 81: 750754.

Giovanni De Simone S, Santos R, Araujo MF, Pinho RT 1994. Preparative isolation of the lectin jacalin by anion-exchange high performance liquid chromatography. J Chromatogrphy A 688: 356-362.

Harry H, Hopkinson DA 1976. Handbook of Enzyme Electrophoresis in Human Genetics, Elsevier Publishing Co. Inc., New York, 120 pp.

Huang XY, Barrios LAM, Vonkhorporn P, Honda S, Albertson DG, Hecht RM 1989. Genomic organization of the glyceraldehyde-3-phosphate dehydrogenase gene family of Caenorhabditis elegans. J Mol Biol 206: 411-424.

Kohl L, Callens M, Wierenga RK, Opperdoes FR, Michels AM 1994. Triosephosphate isomerase of Leishmania mexicana mexicana. Cloning and characterization of the gene, overexpression in Escherichia coli and analysis of the protein. Eur J Biochem 220: 331-338.

Laemmli UK 1970. Cleavage of structural proteins during the assembly of the head of bacteriophage T4. Nature 227: 680-685.

Lowry OH, Rosebrough NJ, Farr AL, Randall RJ 1951. Protein measurement with the folin phenol reagent. J Biol Chem 193: 265-275.

Michels PAM 1989. The glycosome of trypanosomes: Properties and biogenesis of a microbody. Exp
Parasitol 69: 310-315.

Michels PAM, Opperdoes FR 1991. The evolutionary origin of glycosomes. Parasitol Today 7: 105-109.

Misset O, Opperdoes FR 1984. Simultaneous purification of hexokinase, class-I, frutose-biphosphate aldolase, triosephosphate isomerase and phosphoglycerate kinase from Trypanosoma brucei. Eur J Biochem 144: 475-483.

Misset O, Boss OJ.M, Opperdoes FR 1986. Glycolytic enzymes of Trypanosoma brucei. Simultaneous purification, intraglycosomal concentrations and physical properties. Eur J Biochem 157: 441-453.

Misset OE, Van Beeumen J, Lambier AM, Van Der Meer RE, Opperdoes FR 1987. Glyceraldehyde 3-phosphate dehydrogenase from Trypanosoma brucei. Comparison of the glycosomal and cytosolic isoenzymes. Eur J Biochem 162: 501-507.

O'Farrel PZ, Goodman HM, O'Farrel PH 1977. High resolution two-dimensional electrophoresis of basic as well as acidic proteins. Cell 12: 1133-1142.

Opperdoes FR 1987. Compartimentation of carbohydrate metabolism in trypanosomes. Ann Rev Microbiol 41: 127-151.

Opperdoes FR, Wierenga RK, Noble MEM, Hol WGJ, Willson M, Kuntz DA, Callens M, Perié J 1990. Unique properties of glycosomal enzymes, p. 233 246. In N Agabian, A Cerami (eds), Parasites, Molecular Biology, Drugs and Vaccine Design, WileyLiss, New York.

Soares MJ, De Souza W 1988. Cytoplasmic organelles of trypanosomatids: A cytochemical and stereological study. J Submicroscop Cytol Pathol 20: 349-361.

Sullivan DT, Carroll WT, Kanik-Ennulat CL, Hitti YS, Lovett JA, Von Kalm L 1985. Glyceraldehyde-3phosphate dehydrogenase from Drosophila melanogaster. Biol Chem 260: 4345-4350.

Swinkels BW, Gibson WC, Osinga KA, Kramer R, Veeneman GH, Van Boom HJ, Borst P 1986. Characterization of the gene for the microbody (glycosomal) triosephosphate isomerase of Trypanosoma brucei. EMBO J 5: 1291-1298.

Tang CT, Yuksel KÜ, Jacobson TM, Gracy RW 1990. Isoforms of chicken triosephosphate isomerase are due to specific oxidation of cysteine. Arch Biochem Biophys 15: 12-19.

Tetley L, Vickerman K 1990. The glycosoma of trypanosomes: Number and distribution as revealed by electron spectroscopic imaging and 3 -d reconstruction. $R$ Microscop Soc 26: 83-90.

Towbin T, Gordon J 1979. Electrophoretic transfer of proteins from polyacrylamide gels to nitrocellulose sheets: procedures and some applications. Proc Natl Acad Sci 76: 4350-4354.

Willson M, Callens M, Kuntz DA, Perié J, Opperdoes FR 1993. Synthesis and activity of inhibitors highly specific for the glycolytic enzymes from Trypanosoma brucei. Mol Biochem Parasitol 59: 201-210.

Wood DE, Shiller EL 1975. Trypanosoma cruzi: Comparative fatty acid metabolism of the epimastigotes and trypomastigotes in vitro. Exp Parasitol 38: 202 207. 